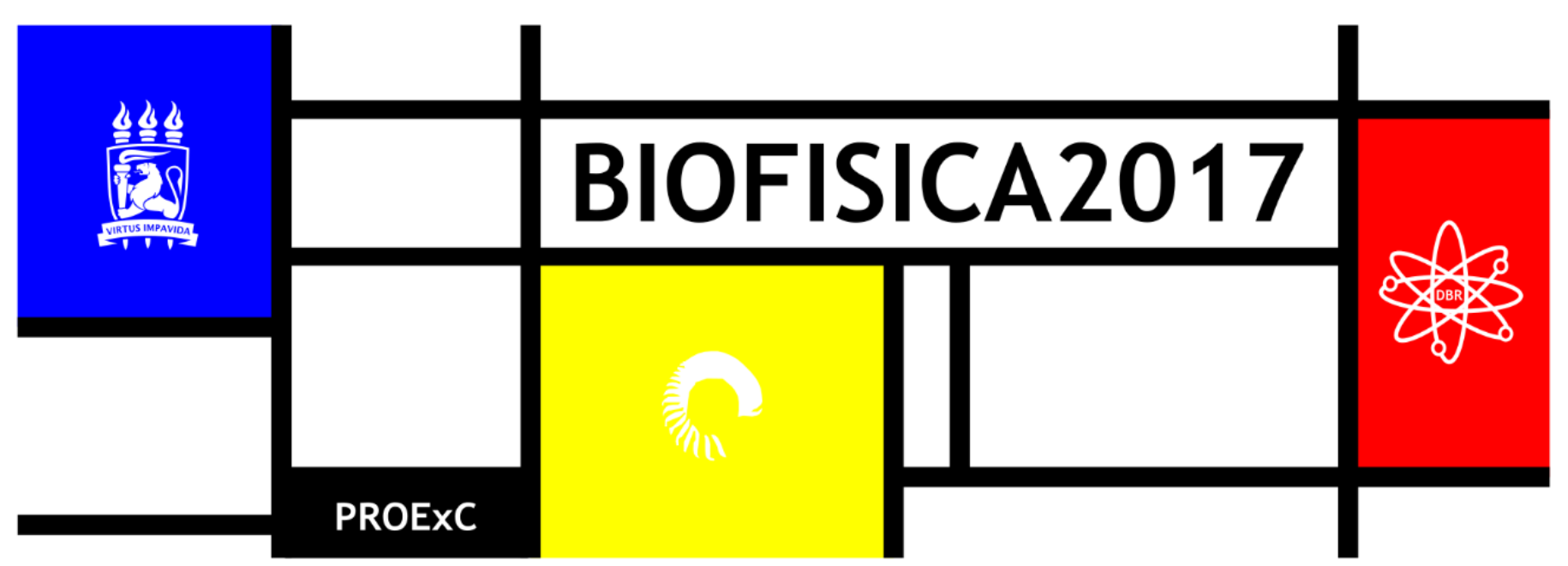

\title{
INSTITUTO TECNOLÓGICO DAS CADEIAS BIOSSUSTENTÁVEIS (ITCBIO): POSSIBILIDADES E OPORTUNIDADES
}

\author{
Cláudia Sampaio de Andrade Lima1,* \\ Departamento de Biofísica e Radiobiologia \\ *claudia.salima@gmail.com
}

\begin{abstract}
O ITCBio é uma Associação Civil, sem fins lucrativos, com estatuto construído para ser reconhecida como uma Organização Social e terá como princípio a excelência na gestão de projetos e recursos. A expectativa é que o ITCBio seja uma OS vinculada ao MCTIC. O Instituto tem como Missão: “Contribuir para o desenvolvimento nacional e regional apoiando, fortalecendo e certificando as cadeias produtivas biossustentáveis através de ações científicas, tecnológicas e inovadoras". Os objetivos estratégico é planejar um ambiente propício à interação e cooperação entre: Governo, Universidades, Centros de Pesquisa e de Desenvolvimento Tecnológico, Empresas, Agências de Fomento, Entidades do Sistema S, Organizações Não Governamentais, Produtores e Comunidades, com vistas ao desenvolvimento de segmentos estratégicos para o país com uma visão econômica e social, voltadas às Cadeias Produtivas de Bioprodutos.
\end{abstract}

